a person referred to in the sub-paragraph which immediately precedes it.

The Archbishop relied upon the fact that two of the existing foundation governors had fulfilled the requirements of paragraphs 10(1)(b) and (c) respectively at the time of their appointment, and thus the requirement of paragraph 5 of the governing instrument was satisfied. He argued that paragraph 10(1) alone defined who was 'eligible for election or appointment as a parent governor', and that paragraph $10(2)$ was relevant only to the method of choosing parent governors. The claimants argued that paragraph 10(2) meant that it was only lawful for the foundation body to appoint governors eligible under paragraphs $10(1)$ (b) or (c) if it was not reasonably practicable to appoint a current parent. In upholding the decision of the first instance judge, the Court of Appeal, by a majority, agreed with the arguments of the Archbishop. The Court of Appeal noted the particular function of foundation governors to secure, preserve and develop the religious character of the school. It was held that to accept the arguments of the claimants would be to place an undue fetter on the discretion of the Archbishop in appointing foundation governors and would create unintended and unreasonable operational difficulties for the Archbishop in exercising his discretion. Sir Richard Buxton, in a dissenting judgment, found that paragraph 10(2) also informed whether a person was 'eligible for election or appointment as a parent governor' and as such the governing body of the school was unlawfully constituted as it did not have two foundation governors who, at the time of their appointment, were eligible for election or appointment as parent governors. [RA]

doi:10.1017/So956618X11000676

\title{
Gilmore v Archdeacon of Charing Cross
}

Court of Arches: April 2011

Clergy discipline - conduct unbecoming - sexual misconduct - penalty

The appellant appealed against the decision of, and the penalty imposed by, a clergy discipline tribunal for conduct unbecoming or inappropriate to the office and work of a clerk in holy orders. The appellant had provided overnight accommodation in the rectory for two servicemen attending a Lesbian, Gay, Bisexual and Transexual Conference in London. The appellant had made indecent proposals of a sexual nature to the two servicemen and persisted in pressing his attentions on them when they had clearly indicated that his attentions were 
unwelcome. The following morning he entered the servicemen's bedroom and masturbated as they were engaged in sexual activity. While noting that the appellant did not pose a risk to vulnerable individuals, the court dismissed the appeal. The court observed the lack of contrition and remorse but acknowledged the brevity of the period over which the misconduct had taken place. The penalty of removal from office and a prohibition for two years was upheld. The transcript of the determination of the Court of Arches, dated May 2011, together with that of the first instance tribunal may be found at $<$ http://www.ecclaw. co.uk/clergydiscipline.php $>$, accessed 16 June 2011. [RA]

doi:10.1017/So956618X11000688

\section{Re Holy Trinity, Horwich \\ Manchester Consistory Court: Tattersall Ch, May 2011 \\ Re-ordering - pews - necessity}

The petitioners sought a faculty to re-order the balcony of a nineteenth-century Grade II listed church. The nave had been re-ordered, reducing its seating area. The petitioners sought to replace nineteenth-century box pews with eight bench pews from the nave and to alter the floor levels so as to provide more flexible space in the balcony area. It was argued that the pews were in poor repair, uncomfortable and incongruous with the newly ordered nave. Growth in attendance and special events meant that the balcony was used occasionally. The petition was recommended by the diocesan advisory committee but not unanimously. The Georgian Group opposed the petition. The Church Buildings Council also opposed the application, arguing that the pews were rare and important survivals illustrating four types of socially graded seating, from 'backless benches presumably for paupers, backed benches for slightly better off people, wide seats and small arm-rests for the wealthier and a range of pews with narrow seats and no arm rests for those in-between'. They were rare examples of such pews in their original church setting. The court held that, although there was some incongruity between the re-ordered nave and the balcony, this was not visible from the nave and could be at least partially rectified by tidying up the balcony and re-staining the pews. The changes sought by removal of the pews were not a matter of necessity but merely of taste and comfort in relation to a balcony that was used infrequently. The faculty was refused. [Catherine Shelley] 